\title{
METABOLISM OF FATTY ACIDS BY TESTICULAR AND EJACULATED RAM SPERMATOZOA
}

\author{
S. C. MILLS and T. W. SGOTT \\ C.S.I.R.O., Division of Animal Physiology, \\ The Ian Clunies Ross Animal Research Laboratory, Prospect, N.S.W., Australia
}

(Received 27th September 1968, revised 28th October 1968)

Previous studies revealed a significant decrease in the content of phospholipids and acyl-esters in spermatozoa during their passage through the epididymis (Scott, Voglmayr \& Setchell, 1967). These results prompted us to investigate whether testicular and ejaculated spermatozoa could utilize fatty acids, which presumably become available to the spermatozoa as a result of phospholipid hydrolysis. The experiments described below show that both cell types were able to metabolize added ${ }^{14} \mathrm{C}$-labelled palmitic and oleic acids.

Testicular and ejaculated semen were obtained using procedures described by Voglmayr, Scott, Setchell \& Waites (1967). The cells were incubated under aerobic conditions for $3 \mathrm{hr}$ at $38^{\circ} \mathrm{C}$ in Krebs-Ringer bicarbonate buffer solution ( $\mathrm{pH} 7.4$ ) containing ${ }^{14} \mathrm{C}$-labelled fatty acid complexed to bovine serum albumin (using Complex B as described by Kessler, Demeny \& Sobotka, 1967); 166 units of penicillin were added to each vessel. At the end of incubation the cells were highly motile; nigrosin-eosin staining (Hancock, 1951) revealed no change in the ratio of live to dead spermatozoa $(80 / 20)$ during the experiment. After incubation, lipids were extracted and fractionated using the techniques described by Scott et al. (1967) and Scott \& Dawson (1968).

Both testicular and ejaculated spermatozoa incorporated radio-activity from $\left[{ }^{14} \mathrm{C}\right]$ palmitic acid and $\left[{ }^{14} \mathrm{C}\right]$ oleic acid into phospholipids and into neutral lipids (Table 1). However, dead spermatozoa (killed by boiling for $10 \mathrm{~min}$ ) failed to incorporate radio-activity into the lipids. The major proportion of radio-activity incorporated into the phospholipids was contained in the choline phosphoglyceride fraction with smaller amounts being present in the ethanolamine lipids and lysolecithin. This pattern of labelling was observed in both testicular and washed ejaculated spermatozoa as well as in ejaculated semen. To characterize the choline plasmalogen and lecithin components further, portions of the phospholipid extract were chromatographed in one dimension on thin layer plates (silica gel $\mathrm{H}$ ) using a solvent system of chloroform:methanol:ammonia (sp. gr. $0 \cdot 88$ ): water (26:14:2:1 by volume). The lipids on the plate were exposed to $\mathrm{HCl}$ fumes as described by Schmid \& Mangold (1966) so as to hydrolyse the choline plasmalogen, and the treated plates were then chromatographed in the same solvent system in the second dimension. Over $90 \%$ of the radio-activity present in the choline phosphoglycerides was recovered in lecithin suggesting minimal labelling of the plasmalogenic form. 
The pattern of labelling of the individual neutral lipids was also similar for testicular and ejaculated spermatozoa. Diglycerides accounted for the majority of incorporated radio-activity, and the 1,2 form had more radio-activity than the 1,3 form. Further, the amount of radio-activity incorporated into the diglycerides isolated from whole semen appeared to be greater than that demonstrated in washed spermatozoa (Table 1). Treatment of the diglyceride fraction with $\mathrm{HCl}$ fumes (Schmid \& Mangold, 1966), revealed that over $90 \%$ of the radio-activity was in diacylated diglycerides. These results, together with data obtained from using $\left[{ }^{14} \mathrm{C}\right]$ glucose (Scott et al., 1967) suggest that the re-synthesis of plasmalogenic lipids (which account for about $50 \%$ of the phospholipid),

TABLE 1

INCORPORATION OF ${ }^{14} \mathrm{C}$ INTO LIPIDS OF TESTICULAR AND EJAGULATED RAM SPERMATOZOA AFTER INGUBATION WITH LABELLED PALMITIC AND OLEIG AGIDS

\begin{tabular}{|c|c|c|c|c|c|c|}
\hline \multirow{3}{*}{ Labelled compound } & \multicolumn{2}{|c|}{$\begin{array}{c}\text { In incubated testicular spermatozoa } \\
\left(\text { counts } / \text { min } / 10^{8} \text { cells }\right)\end{array}$} & \multicolumn{4}{|c|}{$\begin{array}{c}\text { In incubated ejaculated spermatozoa } \\
\left(\text { counts } / \text { min } / 10^{8} \text { cells }\right)\end{array}$} \\
\hline & \multirow{2}{*}{$\begin{array}{c}\text { with } \\
{\left[1-{ }^{14} C\right] \text { palmitic }} \\
\text { acid }\end{array}$} & \multirow{2}{*}{$\begin{array}{c}\text { with } \\
{\left[1-{ }^{14} C\right] \text { oleic }} \\
\text { acid }\end{array}$} & \multicolumn{2}{|c|}{$\stackrel{\text { with }}{\left[1-{ }^{14} C\right] \text { palmitic }}$} & \multicolumn{2}{|c|}{$\stackrel{\text { with }}{\left[1-{ }^{14} \mathrm{C}\right] \text { oleic }}$} \\
\hline & & & $\begin{array}{l}\text { Washed } \\
\text { sperm. }\end{array}$ & $\begin{array}{l}\text { Whole } \\
\text { semen }\end{array}$ & $\begin{array}{l}\text { Washed } \\
\text { sperm. }\end{array}$ & $\begin{array}{l}\text { Whole } \\
\text { semen }\end{array}$ \\
\hline $\begin{array}{l}\text { Phospholipids } \\
\text { Choline } \\
\text { Ethanolamine } \\
\text { Lysolecithin }\end{array}$ & $\begin{array}{r}3447 \\
289 \\
300\end{array}$ & $\begin{array}{r}2024 \\
410 \\
99\end{array}$ & $\begin{array}{l}423 \\
172 \\
127\end{array}$ & $\begin{array}{l}375 \\
270 \\
264\end{array}$ & $\begin{array}{l}659 \\
590 \\
124\end{array}$ & $\begin{array}{r}1386 \\
830 \\
399\end{array}$ \\
\hline $\begin{array}{l}\text { NEUTRAL LIPIDS } \\
\text { Monoglycerides } \\
\text { Diglycerides } \\
\text { Triglycerides } \\
\text { Cholesterol esters }\end{array}$ & $\begin{array}{r}248 \\
5556 \\
558 \\
502\end{array}$ & $\begin{array}{r}194 \\
2961 \\
430 \\
218\end{array}$ & $\begin{array}{r}- \\
4956 \\
38 \\
36\end{array}$ & $\begin{array}{r}-\overline{10266} \\
52 \\
34\end{array}$ & $\begin{array}{r}259 \\
4090 \\
50 \\
-\end{array}$ & $\begin{array}{r}260 \\
7210 \\
38 \\
-\end{array}$ \\
\hline
\end{tabular}

Spermatozoa (4 to $15 \times 10^{8}$ testicular or 26 to $40 \times 10^{8}$ ejaculated) were incubated with KrebsRinger buffer solution containing ${ }^{14} \mathrm{C}$-fatty acids $(2$ to $4 / \mathrm{c} \mu \mathrm{ml}$ of incubation media; specific radio-activity $19 \mu \mathrm{c} / \mu \mathrm{mole})$ for $3 \mathrm{hr}$ at $38^{\circ} \mathrm{C}$. Individual lipids were separated by thin-layer chromatography. Values are counts $/ \mathrm{min} / 10^{8}$ cells and are adjusted to $1 \times 10^{6}$ counts $/ \mathrm{min}$ added per vessel at the commencement of incubation.

and of their precursors in spermatozoa is small or absent; this is in striking contrast to the re-synthesis of their diacylated counterparts.

In further experiments, ejaculated semen and testicular spermatozoa were incubated with [U $\left.{ }^{14} \mathrm{C}\right]$ palmitic acid $(43 \mu \mathrm{g}, 3 \mu \mathrm{c} / \mathrm{vessel})$ to investigate whether this fatty acid was oxidized. Radio-active carbon dioxide was collected (Voglmayr et al., 1967) during a 3-hr incubation. Radio-activity was recovered as carbon dioxide (1130 counts $/ \mathrm{min} / 10^{8}$ testicular cells; 715 counts $/ \mathrm{min} / 10^{8}$ ejaculated cells) indicating that the fatty acid was indeed oxidized. This result confirmed the earlier gas chromatographic analysis of Hartree \& Mann (1961), which indicated that palmitic acid was oxidized by washed ejaculated ram spermatozoa under aerobic conditions.

The authors are grateful to Mr J. K. Voglmayr and Mr K. Turnbull for collecting testicular and ejaculated semen. 


\section{REFERENGES}

Hancock, J. L. (1951) A staining technique for the study of temperature shock in semen. Nature, Lond. $167,323$.

Hartree, E. F. \& Mann, T. (1961) Phospholipids in ram semen: metabolism of plasmalogens and fatty acids. Biochem. $\mathbf{7 . 8 0}, 464$.

Kessler, J. I., Demeny, M. \& Sobotka, H. (1967) Rate of tissue uptake of palmitic acid-[1-14C] complexed with albumin by two different procedures. F. Lipid Res. 8, 185.

Schmm, H. H. O. \& Mangold, H. K. (1966) Alkoxylipids: II. 'Neutral plasmalogens' in the liver oil of the catfish (Hydrolagus colliei). Biochim. biophys. Acta, 125, 182.

Scotr, T. W. \& DAwson, R. M. G. (1968) Metabolism of phospholipids by spermatozoa and seminal plasma. Biochem. F. 108, 457.

Scott, T. W., Voglmayr, J. K. \& Setchell, B. P. (1967) Differences in lipid composition and metabolism between testicular and ejaculated ram spermatozoa. Biochem. F. 102, 456.

Voglmayr, J. K., Scott, T. W., Setchell, B. P. \& Waites, G. M. H. (1967) Metabolism of testicular spermatozoa and characteristics of testicular fluid collected from conscious rams. F. Reprod. Fert. 14,87 . 